\title{
Plant Extractivism Production Disparity Between Northeast Brazil and Brazil
}

\author{
Kalyne de Lourdes da Costa Martins ${ }^{1}$, Thiago Freire Melquíades ${ }^{1}$, \\ José Luiz Pereira de Rezende ${ }^{2}$, Luiz Moreira Coelho Junior ${ }^{1}$
}

${ }^{1}$ Centro de Energias Alternativas e Renováveis - CEAR, Universidade Federal da Paraíba - UFPB, João Pessoa/PB, Brasil ${ }^{2}$ Universidade Federal de Lavras - UFLA, Lavras/MG, Brasil

\begin{abstract}
The present study analyzed the disparity in the gross production value of plant extractivism between Northeast Brazil and Brazil from 1994 to 2012. The following location measures were used: location quotient $(L Q)$, location coefficient $(L C)$, redistribution coefficient $(R E D C)$ and coefficient of geographic association $(\mathrm{Gac})$. The following regional measures were used: specialization coefficient $(S C)$ and restructuring coefficient $(R c)$. Based on the location indicators studied, it was concluded that there is no disparity in plant extracted groups between Northeast Brazil and Brazil. Plant extracted groups explored in Northeast Brazil are relevant for Brazil $(L Q)$, not concentrated $(L C)$, and regionally distributed $(\mathrm{Gac})$. REDC showed no structural changes. The regional measures ( $S C$ and $R c$ ) showed identical specialization, with no changes in the production structure. However, studies on the disparity in Northeast Brazil at smaller regional scales (state, mesoregion, microregion and municipality) are needed.
\end{abstract}

Keywords: forest economy, regional measures, location measures. 


\section{INTRODUCTION}

From the beginning of civilization, forests have been used for the well-being and progress of humanity. Throughout the centuries, humanity has learned to use the available forest resources as a source of commodities such as food, drugs, forage, fertilizers, energy, fibers, resin, gum, building materials, and many others (FAO, 2002).

According to the FAO (2016), 75\% of earth's biodiversity comes from forests, which supply many products and services that enable the world's economic development. Forest products are divided into timber and non-timber products. Forests are essential for hundreds of millions of people, especially in rural and poorer regions in the world, which are concentrated in tropical areas.

The exploitation of forest resources provides an alternative form of employment and income. Plant extractivism can be defined as the process of exploration of native plant resources, including the collection of products such as wood, latex, seeds, fibers, fruits and roots, either in a rational or in a primitive way (IBGE, 2012).

Plant extractivism has been present in Brazil since colonization and shows characteristics that are related to regional peculiarities. In Northeast Brazil, where Brazil's pockets of poverty are concentrated, plant extractivism is an alternative for the generation of income and employment (Clement, 2006; Santos \& Gomes, 2009).

Plant extractivism has become essential to local development in Northeast Brazil. Travassos \& Souza (2014) analyzed the social and economic dynamics of plant extractivism in the Cariri region of the state of Paraíba and reported a strong dependence of the low-income population on timber exploitation. Mota et al. (2008) studied the extractivism and consumption of mangaba (Hancornia speciosa) in Northeast Brazil and reported "domestication" trends to meet the increasing demand. Plant extractivism is therefore relevant in Northeast Brazil, and understanding its behavior at the regional level relative to the national level is necessary.

The regional economy includes spatial differentiation and interrelations between areas within a national system of regions (Souza, 1981). Besides determining which resources are scarce, their distribution in the space is provided through location and regional measures. Location measures serve to identify patterns of spatial concentration or dispersion of activities for a given period of time or between two periods. Regional measures determine the degree of specialization of regional economies and their dynamics over a given period of time (Haddad, 1989). These indicators were used in the following studies: Lima et al. (2006), for land use in southern Brazil; Piacenti et al. (2008), for the location profile of sectorial employment in Brazil; and Mazur et al. (2013), for a location analysis of production of the main crops in the microregion of Campo Mourão, state of Paraná.

There are therefore no studies on the disparity in plant extractivism between Northeast Brazil and Brazil. The present study analyzed the disparity in the gross production value (GPV) of plant extractivism between Northeast Brazil and Brazil from 1994 to 2012.

\section{MATERIALS AND METHODS}

\subsection{Data used}

GPV data for plant extractivism in Northeast Brazil and Brazil between 1994 and 2012 used in the study were retrieved from the Automatic Recovery System (SIDRA) of the Brazilian Institute of Geography and Statistics (IBGE, 2015a).

According to the IBGE (2015b), plant extracted products are classified into the following groups: food; aromatics, medicinals, toxins and dyes; rubbers; waxes; fibers; non-elastic gums; charcoal; firewood; roundwood; oleaginous products; and tanning products. These groups can be decomposed as follows: 1. Food - açai (fruit) (Euterpe ssp.), cashew nut (Anacardium occidentale L.), Brazil nut (Bertholletia excelsa Bonpl.), yerba mate "cancheada" (dried and coarsely ground) (Ilex ssp.), mangaba (fruit) (Hancornia speciosa Gomes), heart of palm (juçara heart of palm Euterpe ssp.), pine nut [Araucaria angustifólia (Bertol.) Kuntze], umbu (fruit) (Spondias tuberosa Arruda), and others; 2. Aromatics, Medicinals, Toxins and Dyes - ipecacuanha [Carapichea ipecacuanha (Brot.) L.Andersson], jaborandi (leaf) (Policarpus ssp.), achiote (seed) (Bixa orellana L.), and others; 3. Rubbers - hevea (coagulated latex) (Hevea ssp.) and hevea (liquid latex) (Hevea ssp.); 4. Waxes - carnauba (wax) [Copernicia prunifera (Mill.) H. E. Moore], carnauba (powder) 
[Copernicia prunifera (Mill.) H. E. Moore], and others; 5. Fibers - buriti (Mauritia flexuosa L.f.), carnauba [Copernicia prunifera (Mill.) H. E. Moore], piassava (Attalea funifera Mart.), and others; 6. Non-elastic gums - sorva (Couma spp.); 7. Charcoal; 8. Firewood;

9. Roundwood; 10. Oleaginous products - babaçu (kernel) (Attalea ssp.), copaíba (oil) (Copaifera ssp.), cumaru (kernel) (Dipteryx ssp.), licuri (fruit) (Syagrus ssp.), oiticica (seed) (Licania rígida Benth.), pequi (kernel) (Caryocar ssp.), tucum (kernel) (Bactris ssp.), and others; and 11. Tanning products - angico (bark) (Anadenanthera ssp.), barbatimão (bark) [Abarema cochliacarpos (Gomes) Barneby \& J. W. Grimes], and others.

The GPV of plant extracted groups for Northeast Brazil and Brazil were deflated for a comparative analysis of different periods. The real GPV of plant extractivism was calculated using the following equation: $L_{r}=\frac{P_{n}}{\text { Index }} * 100$, where $P_{r}=$ real GPV, $P_{n}=$ nominal or current GPV, and Index = an economic indicator. The Brazilian economic indicator used was the General Price Index - Internal Availability (In Portuguese Indice Geral de Preço - Disponibilidae Interna - IGP-DI), base year $2012=100$ (IPEA, 2015).

\subsection{Location and regional measures}

The following location measures were used: location quotient, location coefficient, coefficient of geographic association and redistribution coefficient. The following regional measures were used: specialization coefficient and restructuring coefficient. These location and regional measures are complementary and were calculated as follows:

\subsubsection{Location measures}

The location quotient $(L Q)$ compares the relative size of a given sector and/or production segment for a given region with a reference region (Mazur et al., 2013). $L Q$ is calculated as $L Q=\frac{E_{i j}}{\sum_{j} E_{i j}} / \frac{\sum_{i} E_{j}}{\sum_{i} \sum_{j}^{E_{j i}}}$, where $E_{i j}=\mathrm{GPV}$ of plant extracted group $i$ for Northeast Brazil; $\sum_{j} E_{i j}=\mathrm{GPV}$ of plant extracted group $i$ for Brazil; $\sum_{i} E_{i j}=\mathrm{GPV}$ of plant extractivism for Northeast Brazil; and $\sum_{i} \sum_{j} E_{i j}=\mathrm{GPV}$ of plant extractivism for Brazil. An $L Q$ higher than 1 indicates that the activity analyzed is relevant for the studied region.
The location coefficient $(L C)$ compares the GPV percentage distribution for a given product and region with a reference region (Lima et al., 2006). $L C$ is calculated as $L C_{i}=\frac{\sum_{j}\left|\left(E_{i j} / \sum_{j} E_{i j}\right)-\left(\sum_{i} E_{i j} / \sum_{i} \sum_{j} E_{i j}\right)\right|}{2}$ where $E_{i j}=\mathrm{GPV}$ of plant extracted group $i$ for Northeast Brazil; $\sum_{j} E_{i j}=\mathrm{GPV}$ of plant extracted group $i$ for Brazil; $\sum_{i} E_{i j}=\mathrm{GPV}$ of plant extractivism for Northeast Brazil; and $\sum_{i} \sum_{j} E_{i j}=\mathrm{GPV}$ of plant extractivism for Brazil.

An $L C$ of 0 means that the regional distribution of the GPV of plant extracted group $i$ is the same for Northeast Brazil and for Brazil, whereas an $L C$ of 1 means that the regional concentration of GPV is higher for Northeast Brazil than for the whole reference region.

The coefficient of geographic association ( $\mathrm{Gac}$ ) indicates the geographic association between two products ( $i$ and $k$ ) and varies between 0 and 1 . Values close to 0 indicate that the regional distributions of GPV are equal between plant extracted group $i$ and group $k$, showing that the location patterns of the two products are geographically associated. Values close to 1 indicate no association (Piacenti et al., 2008). Gac is calculated

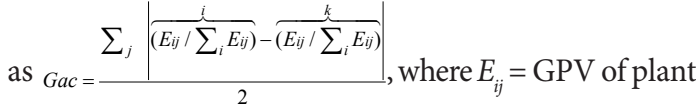
extracted group $i$ for Northeast Brazil and $\sum_{i} E_{i j}=\mathrm{GPV}$ of plant extractivism for Northeast Brazil.

The redistribution coefficient (REDC) compares the percentage distribution of the GPV of a plant extracted group for Northeast Brazil and Brazil in two periods of time, thereby detecting patterns of spatial concentration or dispersion in GPV for a given plant extracted group over time (Piacenti et al., 2008). REDC varies between 0 and 1 . Values close to 0 indicate no significant differences in the spatial location pattern for plant extractivism GPV between Northeast Brazil and Brazil, whereas the opposite is true for values close to 1. REDC is calculated as $R E D C=\frac{\sum_{j}\left|\frac{\left.\sum_{E i j} / \sum_{j} E_{i j}\right)}{\left(E_{i j} / \sum_{j}^{t_{i j}}\right)}\right|}{2}$, where $E_{i j}=$ GPV of plant extracted group $i$ for Northeast Brazil and $\sum_{j} E_{i j}=\mathrm{GPV}$ of plant extracted group $i$ for Brazil. The following periods were observed: 1994 to 2000, 1994 to 2006, and 1994 to 2012.

\subsubsection{Regional measures}

The specialization coefficient $(S C)$ is a regional measure that compares the economy of a given region with a reference region. An $S C$ value of 0 means that the composition is equal between the studied and 
the reference region, whereas values close or equal to 1 indicate a high degree of specialization associated with a given product (Lima et al., 2006). SC is calculated as $S C=\frac{\sum_{i}\left|\left(E_{i j} / \sum_{i} E_{i j}\right)-\left(\sum_{j} E_{i j} / \sum_{i} \sum_{j} E_{i j}\right)\right|}{2}$, where $E_{i j}=\mathrm{GPV}$ of plant extracted group $i$ for Northeast Brazil; $\sum_{j} E_{i j}=\mathrm{GPV}$ of plant extracted group $i$ for Brazil; $\sum_{i} E_{i j}=\mathrm{GPV}$ of plant extractivism for Northeast Brazil; and $\sum_{i} \sum_{j} E_{i j}=\mathrm{GPV}$ of plant extractivism for Brazil.

The restructuring coefficient $(R c)$ compares the production structure of a given region between two periods, determining the differences in the degree of specialization of the production. An $R C$ of 0 indicates no changes to the production structure of a given product for the region, and an $R C$ of 1 indicates significant restructuring (Piacenti et al., 2008). $R C$ is calculated as $R c=\frac{\sum_{i}|\overbrace{\left(E_{i j} / \sum_{i} E_{i j}\right)}^{t_{0}}-\overbrace{\left(E_{i j} / \sum_{i} E_{i j}\right)}^{t_{1}}|}{2}$, where $E_{i j}=\mathrm{GPV}$ of plant extracted group $i$ for Northeast Brazil and $\sum_{i} E_{i j}=\mathrm{GPV}$ of plant extractivism for Northeast Brazil. The following periods were observed: 1994 to 2000, 1994 to 2006 , and 1994 to 2012.

\section{RESULTS AND DISCUSSION}

The evolution of the GPV of different plant extracted groups for Northeast Brazil and Brazil between 1994 and 2012, corrected by the IGP-DI (base year $2012=100$ ), is presented in Table 1. Plant extractivism GPV decreased less for Northeast Brazil (-3.08\% p.a.) than for Brazil $(-6.53 \%$ p.a.) in the analyzed period.

In the period between 1994 and 2012, the greatest decrease in GPV was observed for food products for Brazil (-1.19\% p.a.), whereas an increase of $0.92 \%$ p.a. was seen for Northeast Brazil. As for aromatics, medicinals, toxins and dyes, the GPV tended to decrease, both in Brazil and in Northeast Brazil, with a decrease of $10.58 \%$ p.a. for Brazil. This decrease was explained by a decrease in the quantity produced, with achiote (seed) being the main responsible for this drop. Northeast Brazil is the main national producer of waxes and fibers. Charcoal GPV decreased 2.13\% p.a. for Brazil, whereas increased 3.34\% p.a. for Northeast Brazil. Firewood GPV decreased $4.04 \%$ p.a. for Brazil and $3.82 \%$ p.a. for Northeast Brazil.

The evolution of the location quotient $(L Q)$ and location coefficient $(L C)$ for plant extractivism GPV for Northeast Brazil compared to Brazil in the period between 1994 and 2012 is presented in Figure 1. The evolution of the $L Q$ for plant extracted products for Northeast Brazil compared to Brazil (1994 to 2012) is presented in Figure 1a. Except for food and roundwood, the GPV of the different plant extracted groups was relevant for the economy of Northeast Brazil, compared to Brazil, for the period between 1994 and 2012.

Regarding forest wood products, firewood (with a higher $L Q$ ) was more representative than charcoal until

Table 1. Evolution of the plant extractivism real gross production value (R\$1000.00) for Northeast Brazil and Brazil between 1994 and 2012 (IGP-DI base year $2012=100$ ).

\begin{tabular}{|c|c|c|c|c|c|c|c|c|}
\hline \multirow{2}{*}{ Products } & \multicolumn{2}{|c|}{1994} & \multicolumn{2}{|c|}{2000} & \multicolumn{2}{|c|}{2006} & \multicolumn{2}{|c|}{2012} \\
\hline & BR & NE & BR & NE & BR & NE & BR & NE \\
\hline Food & 754.37 & 27.37 & 498.39 & 23.01 & 382.37 & 24.69 & 608.05 & 32.31 \\
\hline Arom., Med., Tox. and Dyes* & 12.58 & 8.15 & 7.42 & 5.55 & 5.34 & 2.11 & 1.68 & 1.21 \\
\hline Rubbers & 40.44 & - & 19.06 & - & 11.90 & 0.01 & 6.68 & 0.06 \\
\hline Waxes & 118.27 & 118.27 & 70.79 & 70.78 & 91.040 & 91.03 & 113.60 & 113.60 \\
\hline Fibers & 258.18 & 254.84 & 259.52 & 231.79 & 133.56 & 111.14 & 114.12 & 109.79 \\
\hline Non-elastic gum & 0.16 & - & 0.19 & - & 0.21 & - & 0.01 & - \\
\hline Charcoal & 851.64 & 164.23 & 540.48 & 143.58 & $1,119.40$ & 365.86 & 577.79 & 297.10 \\
\hline Firewood & $1,432.53$ & 593.25 & 732.47 & 305.89 & 742.06 & 296.70 & 681.64 & 294.09 \\
\hline Roundwood & $10,708.86$ & 658.63 & $2,363.22$ & 303.47 & $2,809.57$ & 604.86 & $2,006.51$ & 139.49 \\
\hline Oleaginous products & 152.59 & 143.48 & 136.17 & 129.02 & 167.95 & 158.96 & 139.10 & 132.99 \\
\hline Tanning products & 0.36 & 0.31 & 0.240 & 0.23 & 0.14 & 0.13 & 0.16 & 0.14 \\
\hline Total & $14,329.99$ & $1,968.53$ & $4,627.94$ & $1,213.32$ & $5,463.55$ & $1,655.48$ & $4,249.33$ & $1,120.77$ \\
\hline
\end{tabular}

*Aromatics, Medicinals, Toxins and Dyes. Source: IBGE (2015a). 

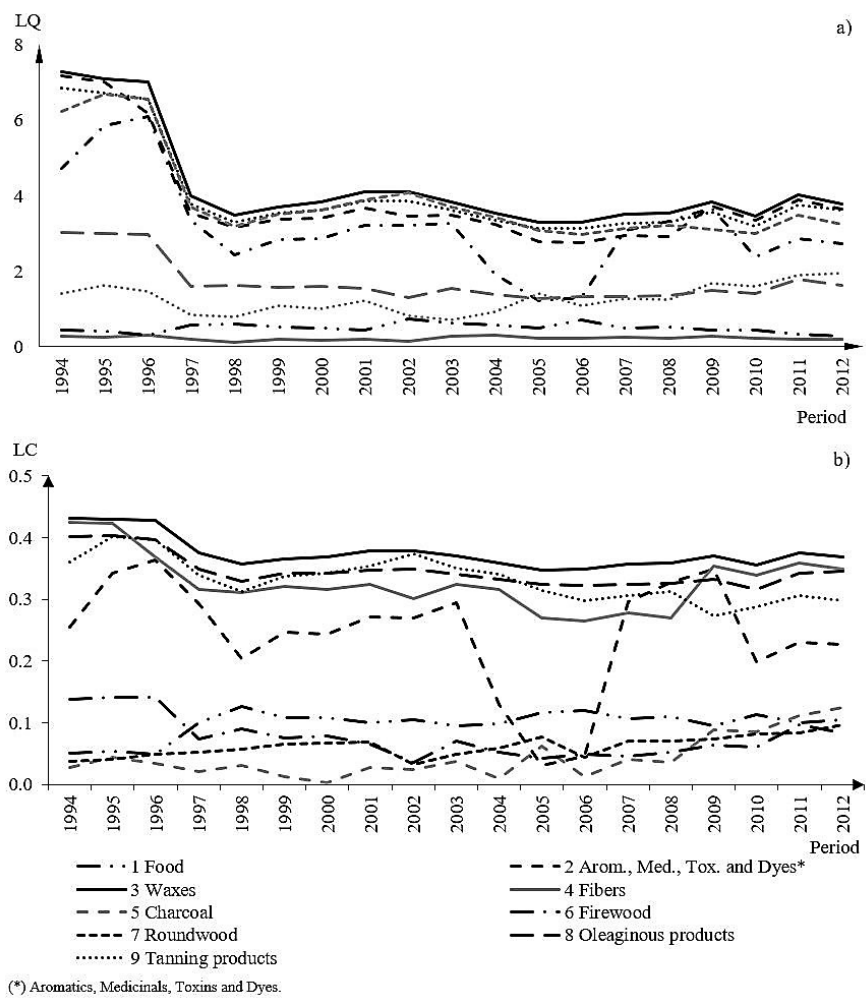

Figure 1. Evolution of the (a) location quotient (LQ) and (b) location coefficient (LC) for the gross production value of plant extractivism for Northeast Brazil compared to Brazil in the period between 1994 and 2012.

2008. Between 2009 and 2012, charcoal became more representative than firewood, as indicated by the $L Q$.

According to the IBGE (2008), the states of Maranhão and Piauí stood out due to an expansion of agricultural borders and increased demand for native charcoal by steel industries in the region, and were responsible for $23.9 \%$ and $7.6 \%$ of the national extractivist production, respectively. According to the IBGE (2010), forest inspections were intensified because of abuses of illegal deforestation in Northeast Brazil, which resulted in the replacement of firewood with liquefied petroleum gas (LPG). However, this difference between the $L Q$ for charcoal and for firewood was not significant after 2008, as both presented $L Q$ values of the same magnitude for Northeast Brazil.

The evolution of $L C$ for plant extracted products for Northeast Brazil compared to Brazil (1994 to 2012) is presented in Figure 1b. Plant extractivism showed similar distributions for Northeast Brazil and Brazil. All plant extracted groups showed an $L C$ lower than 1 , indicating that the concentration was not higher for
Northeast Brazil than for Brazil. The GPV of waxes stood out among the plant extracted groups. Carnauba wax was one of the main products in Piauís list of exported products (IBGE, 2010). In 2010, for example, Piauí was responsible for the production of 12982 tons of carnauba powder from a total (Northeast) of 18802 tons, whereas Ceará was responsible for 5267 tons, Maranhão for 506 tons, and Rio Grande do Norte for 46 tons. In 2010, the municipalities with greater production of carnauba were located in Piauí (13), Ceará (6) and Maranhão (1). Together, these municipalities accounted for $55 \%$ of the national production.

The Gac for plant extracted products for Northeast Brazil between 1994 and 2012 are presented in Table 2. The Gac indicated that all plant extracted groups for Northeast Brazil were geographically associated for the period between 1994 and 2012 (Table 2). The Gac values were close to 0 , i.e., there was no regional disparity between groups for Northeast Brazil.

In 1994, no regional disparity was observed for the following associations between plant extracted groups 
Table 2. Coefficient of geographic association for plant extracted groups for Northeast Brazil between 1994 and 2012.

\begin{tabular}{lllll|}
\hline \multicolumn{1}{c}{ Products } & $\mathbf{1 9 9 4}$ & $\mathbf{2 0 0 0}$ & $\mathbf{2 0 0 6}$ & $\mathbf{2 0 1 2}$ \\
\hline Food and Charcoal & 0.0348 & 0.0499 & 0.1030 & 0.1181 \\
\hline Food and Firewood & 0.1437 & 0.1166 & 0.0821 & 0.1169 \\
Food and Roundwood & 0.1603 & 0.1156 & 0.1752 & 0.0478 \\
\hline Charcoal and Firewood & 0.1090 & 0.0669 & 0.0209 & 0.0013 \\
\hline Charcoal and Roundwood & 0.1256 & 0.0659 & 0.0729 & 0.0703 \\
\hline Charcoal and Oleaginous products & 0.0053 & 0.0060 & 0.0629 & 0.0732 \\
\hline Charcoal and Tanning products & 0.0416 & 0.0591 & 0.1105 & 0.1325 \\
\hline Firewood and Roundwood & 0.0166 & 0.0010 & 0.0931 & 0.0690 \\
\hline Firewood and Oleaginous products & 0.1142 & 0.0729 & 0.0416 & 0.0719 \\
\hline Firewood and Tanning products & 0.1506 & 0.1260 & 0.0896 & 0.1311 \\
\hline Roundwood and Oleaginous products & 0.1308 & 0.0719 & 0.1347 & 0.0029 \\
\hline Roundwood and Tanning products & 0.1672 & 0.1250 & 0.1826 & 0.0621 \\
\hline
\end{tabular}

for Northeast Brazil, as indicated by Gac: charcoal and oleaginous products (0.0053), firewood and roundwood (0.0166), and foods and charcoal (0.0348). The group with lower distribution was roundwood and tanning products $(0.1672)$. The temporal dynamics between 1994 and 2000 showed that firewood and roundwood (0.0010) had higher geographical association than the other groups. Food and charcoal groups showed an increase in Gac of 0.0499 . The associations with the lowest regional distribution, as indicated by higher Gac values, were found between firewood and tanning products $(0.1260)$, roundwood and tanning products (0.1250), and foods and firewood (0.1166).

In 2006, the products with higher values of geographical association (lower $\mathrm{Gac}$ ) were charcoal and firewood (0.0209), firewood and oleaginous products (0.0416), and charcoal and oleaginous products (0.0629). Compared to the previous years, there was an increase in $G a c$, indicating a decrease in geographical association, for the following groups: foods and charcoal (0.1030), foods and roundwood (0.1752), charcoal and oleaginous products (0.0629), charcoal and tanning products $(0.1105)$, firewood and roundwood (0.0931), roundwood and oleaginous products (0.1347), and roundwood and tanning products (0.1826). Between 2006 and 2012, Gac increased for the following groups: foods and charcoal (0.1181), foods and firewood (0.1169), charcoal and oleaginous products $(0.0732)$, charcoal and tanning products (0.1325), firewood and oleaginous products (0.0719), and firewood and tanning products (0.1311).
The redistribution coefficients $(R E D C)$ for different plant extracted groups for Northeast Brazil compared to Brazil for the period between 1994 and 2012 are presented in Table 3. REDC values for plant extracted groups were close to 0 , showing no relevant differences in the spatial pattern of location between 1994 and 2000, 1994 and 2006, and 1994 and 2012.

Between 1994 and 2000, the most significant REDC values (significant changes in the spatial pattern of location) for the studied plant extracted groups were observed for aromatics, medicinals, toxins and dyes (0.0499), fibers (0.0469) and tanning products (0.0442). No significant changes in the spatial pattern of location of GPV, as indicated by the REDC, were observed for fibers (0.0001). Between 1994 and 2006, compared to 1994 and 2000, there was an increase in the REDC for the following groups: food (0.0141), aromatics, medicinals and toxins (0.1264), fibers (0.0775), charcoal (0.0670), firewood (0.0071) and roundwood (0.0769). These groups showed changes in the spatial pattern of production location, but these changes were not relevant at the regional level.

The REDC decreased between 1994 and 2012 compared to 1994 and 2006 for the following products: food (0.0084), aromatics, medicinals, toxins and dyes (0.0357), fibers (0.0125), roundwood (0.0040) and tanning products $(0.0004)$. This means that there were less changes to the spatial pattern of production between 1994 and 2012 than between 1994 and 2006 .

The evolution of the specialization coefficient (SC) for different plant extracted products for Northeast Brazil compared to Brazil between 1994 and 2012 is 
Table 3. Redistribution coefficient for plant extracted groups for Northeast Brazil compared to Brazil between 1994 and 2012.

\begin{tabular}{|c|c|c|c|}
\hline Products & 1994 and 2000 & 1994 and 2006 & 1994 and 2012 \\
\hline Food & 0.0049 & 0.0141 & 0.0084 \\
\hline Aromatics, Medicinals, Toxins and Dyes & 0.0499 & 0.1264 & 0.0357 \\
\hline Rubbers & - & - & - \\
\hline Waxes & 0.0001 & 0.0001 & 0.0000 \\
\hline Fibers & 0.0469 & 0.0775 & 0.0125 \\
\hline Non-elastic gums & - & - & - \\
\hline Charcoal & 0.0364 & 0.0670 & 0.1607 \\
\hline Firewood & 0.0017 & 0.0071 & 0.0087 \\
\hline Roundwood & 0.0334 & 0.0769 & 0.0040 \\
\hline Oleaginous products & 0.0036 & 0.0031 & 0.0079 \\
\hline Tanning products & 0.0442 & 0.0209 & 0.0004 \\
\hline
\end{tabular}

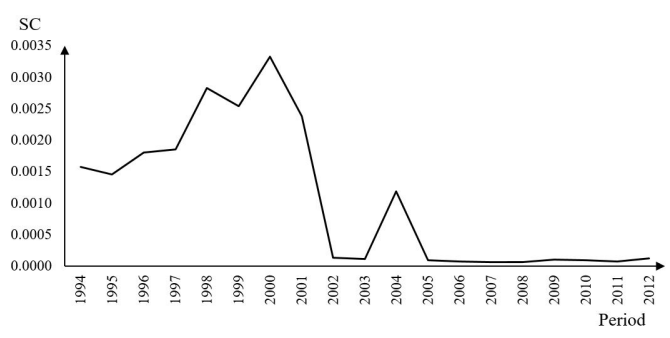

Figure 2. Evolution of the specialization coefficient (SC) for different plant extracted products for Northeast Brazil compared to Brazil between 1994 and 2012.

presented in Figure 2. No significant differences in specialization were observed for plant extracted groups between Northeast Brazil and Brazil, as all SC values were lower than 1 .

The restructuring coefficient $(R C)$ for plant extracted products for Northeast Brazil between 1994 and 2012 is presented in Table 4. For the periods between 1994 and 2000, 1994 and 2006, and 1994 and 2012, the RC was close to 0 . This indicates that there were no changes to the production structure for the plant extracted groups studied during these periods for Northeast Brazil.

It is noteworthy that Northeast Brazil shows a composition that is similar but not identical to that of Brazil, as the values for the plant extracted groups were close to 0 during the studied period. This similarity is explained by the production of waxes and fibers, considered relevant group to the economy of Northeast Brazil.
The GPV of the waxes and fibers group is similar for Northeast Brazil and Brazil. This indicates specialization for this group, directly affecting the $S C$, because it had a low participation in the total plant extractivism GPV for Brazil. In Brazil, the main roundwood producers are the states of Pará, Mato Grosso, Bahia, Amazonas and Rondônia (IBGE, 2010). The state of Bahia is the main responsible for roundwood having a higher $S C$ than other extractivism products in Northeast Brazil. In 2010, the state of Bahia was responsible for $1052983 \mathrm{~m}^{3}$ of the total $12658209 \mathrm{~m}^{3}$ of roundwood produced, with the most important municipalities being Riacho de Santana and Serra do Ramalho.

Between 1994 and 2000, the plant extracted groups that showed no changes in production structure were tanning products $(0.0000)$, aromatics, medicinals, toxins and dyes (0.0002), and waxes (0.0009). The $R C$ of firewood (0.0688) increased between 1994 and 2006 compared to the period between 1994 and 2000, indicating small changes to the production structure that were not significant. During this period, the groups presenting no changes in structure were the same, namely, tanning products (0.0000), food (0.0005), and aromatics, medicinals, toxins and dyes (0.0014).

For 1994 and 2012, the $R C$ increased compared to the remaining years for the following products: food (0.0075), aromatics, medicinals, toxins and dyes (0.0015), waxes (0.0206), charcoal (0.0908), roundwood (0.1051), and oleaginous products (0.0229). These values indicate no significant changes in the production structure, but it should be highlighted that firewood showed a lower $R C$ than that of the remaining years (0.0195). 
Table 4. Restructuring coefficients for different plant extracted products for Northeast Brazil between 1994 and 2012.

\begin{tabular}{|c|c|c|c|}
\hline Products & 1994 and 2000 & 1994 and 2006 & 1994 and 2012 \\
\hline Food & 0.0025 & 0.0005 & 0.0075 \\
\hline Aromatics, Med., Tox. and Dyes* & 0.0002 & 0.0014 & 0.0015 \\
\hline Rubbers & - & - & - \\
\hline Waxes & 0.0009 & 0.0025 & 0.0206 \\
\hline Fibers & 0.0308 & 0.0312 & 0.0157 \\
\hline Non-elastic gums & - & - & - \\
\hline Charcoal & 0.0174 & 0.0688 & 0.0908 \\
\hline Firewood & 0.0246 & 0.0611 & 0.0195 \\
\hline Roundwood & 0.0422 & 0.0154 & 0.1051 \\
\hline Oleaginous products & 0.0167 & 0.0116 & 0.0229 \\
\hline Tanning products & 0.0000 & 0.0000 & 0.0000 \\
\hline
\end{tabular}

*Aromatics, Medicinals, Toxins and Dyes.

\section{CONCLUSIONS}

For the conditions of the present study, it is concluded that there is no disparity in plant extractivism between Northeast Brazil and Brazil according to the location indicators studied ( $L Q, L C, G a c, R E D C$ ). The $L Q$ of plant extracted groups was more relevant to the economy of Northeast Brazil compared to Brazil for the period between 1994 and 2012. LC values lower than 1 indicated that plant extractivism is not more concentrated for Northeast Brazil than for Brazil. The Gac showed that plant extracted groups were regionally distributed in Northeast Brazil. The REDC showed no structural changes between 1994 and 2000, 2006 and 2012. The level of regional specialization for regional measures (SC and RC) was identical for Northeast Brazil and Brazil, with no changes in the production structure during the studied period. However, studies of disparity for different plant extracted groups in Northeast Brazil at smaller regional scales (state, mesoregion, microregion and municipality) are needed.

\section{ACKNOWLEDGEMENTS}

The authors acknowledge the support of the National Council for Scientific and Technological Development (CNPQ), Brazil.

\section{SUBMISSION STATUS}

Received: 4 oct., 2017

Accepted: 26 oct., 2017

\section{CORRESPONDENCE TO}

\section{Luiz Moreira Coelho Junior}

Departamento de Engenharia de Energias

Renováveis, Centro de Energias Alternativas e Renováveis - CEAR, Universidade Federal da Paraíba - UFPB, Cidade Universitária, CP 5115, CEP 58051-900, João Pessoa, PB, Brasil e-mail: luiz@cear.ufpb.br

\section{FINANCIAL SUPPORT}

National Council for Scientific and Technological Development (CNPq) - Brazil (project no ${ }^{\circ} 454830 / 2014-9$ ).

\section{REFERENCES}

Clement CR. A lógica do mercado e o futuro da produção extrativista. In: Kubo RR, Bassi JB, Coelho-de-Souza G, Alencar NL, Medeiros PM, Albuquerque UP, editores. Atualidades em etnobiologia e etnoecologia. Recife: Nupeea: Sociedade Brasileira de Etnobiologia e etnoecologia; 2006. p. 135-150.

Food and Agriculture Organization of the United Nations - FAO. State of the world's forests. Rome: FAO; 2002. 126 p.

Food and Agriculture Organization of the United Nations - FAO. State of the world's forests. Rome: FAO; 2016. 107 p.

Haddad PR. Medidas de localização e de especialização. In: Haddad PR, editor. Economia regional: teorias e métodos de análise. Fortaleza: BNB: ETENE; 1989. p. 225-248. (Estudos Econômico e Sociais, 36).

Instituto Brasileiro de Geografia e Estatística - IBGE. Produção da extração vegetal e da silvicultura [online]. Rio de Janeiro: Sistema IBGE de Recuperação Automática - 
SIDRA; 2015a [cited 2015 Jul 12]. Available from: https:// sidra.ibge.gov.br/pesquisa/pevs/quadros/brasil/2015

Instituto Brasileiro de Geografia e Estatística - IBGE. Produção da extração vegetal e da silvicultura. Vol. 23. Rio de Janeiro: IBGE; 2008. 47 p.

Instituto Brasileiro de Geografia e Estatística - IBGE. Produção da extração vegetal e da silvicultura. Vol. 25. Rio de Janeiro: IBGE; 2010.

Instituto Brasileiro de Geografia e Estatística - IBGE. Produção da extração vegetal e da silvicultura. Vol. 27. Rio de Janeiro: IBGE; 2012. 63 p.

Instituto Brasileiro de Geografia e Estatística - IBGE. Produção da extração vegetal e da silvicultura. Vol. 30. Rio de Janeiro: IBGE; 2015b. 48 p.

Instituto de Pesquisa Econômicas Aplicadas - IPEA. Ipeadata [online]. Brasília: IPEA; 2015 [cited 2015 May 12]. Available from: http://www.ipeadata.gov.br

Lima JF, Alves LR, Piffer M, Piacenti CA. Análise regional das mesorregiões do estado do Paraná no final do século XX. Revista de Análisis Económico 2006; 24(46): 7-25. https://doi.org/10.22456/2176-5456.10845.
Mazur AI, Romero EA, Ecker AEA. Análise Locacional da produção das principais culturas na microrregião de Campo Mourão - Paraná. Revista em Agronegócios e Meio Ambiente 2013; 6(1): 31-45.

Mota DM, Schmitz H, Silva JF Jr. Atores, canais de comercialização e consumo da mangaba no Nordeste brasileiro. Revista de Economia e Sociologia Rural 2008; 46(1): 121-143. http://dx.doi.org/10.1590/S010320032008000100006 .

Piacenti C, Alves LR, Lima JFO. Perfil locacional do emprego setorial no Brasil. Revista Economica do Nordeste 2008; 39(3): 482-502.

Santos SCJ, Gomes LJ. Consumo e procedência de lenha pelos estabelecimentos comerciais de Aracaju - SE. Revista da Fapese 2009; 5(1): 155-164.

Souza NJ. Economia regional: conceitos e fundamentos teóricos. Revista Perspectiva Econômica. 1981; 11(32): 67-102.

Travassos IS, Souza BI. Os negócios da lenha: indústria, desmatamento e desertificação no Cariri Paraibano. Revista Espaço e Tempo. 2014; 18(2): 329-340. https:// doi.org/10.11606/issn.2179-0892.geousp.2014.84536. 